\title{
The effects of high salinity on nitrogen removal and the formation characteristics of aerobic granular sludge
}

\author{
HyunGu Kim ${ }^{1}$, DaeHee $\mathrm{Ahn}^{1,2^{\dagger}}$ \\ ${ }^{1}$ BlueBank Co., Ltd., Business Incubator Center, Myongji University, Yongin 17058, Republic of Korea \\ ${ }^{2}$ Department of Environmental Engineering and Energy, Myongji University, Yongin 17058, Republic of Korea
}

\begin{abstract}
This study investigated the biological treatment of high-salinity wastewater using aerobic granular sludge (AGS). The removal performance, AGS characteristics, and microbial community were examined under salinity conditions ranging from 0.5 to 3.0 wt. $\%$. When the salinity was increased, the removal efficiency of the chemical oxygen demand did not change substantially. The mean removal efficiency of $\mathrm{NH}_{4}{ }^{+}-\mathrm{N}$ ranged from 43.7 to $72.6 \%$ during the operation period. As for the concentration of extracellular polymeric substances (EPS), the polysaccharide/protein (PS/PN) ratio increased from 0.37 to 0.57 . The concentrations of the mixed liquor suspended solid (MLSS) and mixed liquor volatile suspended solid (MLVSS) were 4,560 and 3,170 mg/L, respectively, in the end phase, and the MLVSS/MLSS ratio decreased from 0.81 to 0.69 . The sludge volume index $\left(\mathrm{SVI}_{30}\right)$ decreased linearly from 88 to $58 \mathrm{~mL} / \mathrm{g}$. In the microbial community analysis, Nitrosomonas species accounted for $22.9 \%$ of the total bacteria in the initial phase, whereas Halomonas accounted for $43.2 \%$ in the end phase. Hence, the gradually increased salinity appears to facilitate the dominance of halophilic microorganisms in the long-term operation of an AGS-based biological treatment system and the stable retention of AGS.
\end{abstract}

Keywords: Aerobic granular sludge (AGS), Extracelluar polymeric substances (EPS), Nitrogen, Sequencing batch reactor (SBR), Salinity

\section{Introduction}

The intrusion of seawater caused by excessive groundwater extraction and the rising sea level due to global warming add to the volume of high-salinity wastewater flowing into the sewage treatment plants in coastal areas [1-3]. Furthermore, the high-salinity wastewater generated by marine aquaculture and seafood processing industries is known to be a factor impacting the efficient treatment of the contamination sources in established wastewater treatment plants $[4,5]$.

The current physicochemical treatment technologies for saline wastewater include capacitive deionization, membrane separation, ion exchange, and electrodialysis [6-10]. These processes, however, are costly and require control measures against secondary contamination; thus, they are only applicable under specific conditions. In addition, physicochemical treatment is not suitable for high-salinity wastewater due to its low removal efficiency of dissolved chemical oxygen demand (COD) and its high consumption of chemicals. By contrast, biological treatment processes are econom- ical and avoid secondary contamination, and thus are preferred over physicochemical technologies [11, 12]. Yet, high-salinity wastewater contains an abundance of organic compounds and soluble inorganic salt, which directly or indirectly inhibits the cell division and proliferation of microorganisms in wastewater treatment plants and may ultimately be detrimental to the growth, productivity, and performance of the microorganisms [13, 14]. In particular, when highly saline wastewater is biologically treated, osmotic pressure causes the dewatering of the cell sap resulting in plasmolysis, or the contraction of the microorganism protoplast, and the decline in microbial activation $[15,16]$. Thus, much attention has been paid to the biological treatment of high-salinity wastewater from the perspectives of sewerage engineering and marine environment protection. During the past several decades, diverse treatment methods and reactors have been developed to improve the efficiency of biological treatment of highly saline wastewater [17-21]. However, previous studies on the contamination removal performance, e.g. the efficiency of removing organic matter and nitrogen from saline wastewater, used the general activated sludge
This is an Open Access article distributed under the terms of the Creative Commons Attribution Non-Commercial License (http://creativecommons.org/licenses/by-nc/3.0/) which permits unrestricted non-commercial use, distribution, and reproduction in any medium, provided the original work is properly cited.

Copyright (C) 2020 Korean Society of Environmental Engineers
Received June 3, 2019 Accepted September 9, 2019

${ }^{\dagger}$ Corresponding author

Email: dhahn@mju.ac.kr

Tel: +82-31-321-5901 Fax: +82-505-300-5901

ORCID: 0000-0002-6031-3610 
process, and mainly involved $\mathrm{NaCl}$ among other salts [22-25].

Lately, the aerobic granular sludge (AGS) process based on the wastewater treatment system has attracted attention due to the higher concentration of microorganisms, higher treatment efficiency, superior sedimentation, and stronger resistance to shock load compared to the activated sludge [26-29]. The AGS is reported to settle more stably in sequencing batch reactors (SBRs) than in continuous flow reactors, and more regularly under highly saline conditions [30, 31].

Research on the AGS-based treatment of high-salinity wastewater largely revolves around the formation characteristics of AGS, granular stability, and microbial community analysis. That said, most studies are similar to the existing research based on the activated sludge in that they involve only $\mathrm{NaCl}$, whereas diverse ionic substances in seawater have not been well studied [32-34]. Hence, this study explored the characteristic biological removal of nitrogen from the AGS and the formation thereof using the SBR under the condition of gradually increased seawater salinity. This paper also discusses the efficient biological treatment of high-salinity wastewater based on the following: (i) evaluation of the removal efficiency of organic matter and nitrogen; (ii) analysis of extracellular polymeric substances (EPS) and sedimentation; and (iii) observation of the microbial surface and analysis of the microbial community.

\section{Materials and Methods}

\subsection{Synthetic Wastewater}

Synthetic saline wastewater was prepared by referring to the appearance of real seawater [35-36]. During the operation period, the salinity was increased stepwise: $0.5,1.0,1.5,2.0,2.5$, and 3.0 wt.\% (Table 1). The influent carbon/nitrogen $(\mathrm{C} / \mathrm{N})$ ratio was set at 8 in the reactor with an influent COD and TN of 200 and 25 $\mathrm{mg} / \mathrm{L}$, respectively, during the operation period. $\mathrm{CH}_{3} \mathrm{COONa}$ and $\mathrm{NH}_{4} \mathrm{Cl}$ were used to prepare the COD and $\mathrm{NH}_{4}{ }^{+}-\mathrm{N}$, respectively. $\mathrm{KCl}, \mathrm{NaCl}, \mathrm{MgCl}_{2}, \mathrm{CaCl}_{2}$, and $\mathrm{MgSO}_{4}$ (Samchun Chemical Co. Ltd., Korea) were used to prepare the salinity. The alkalinity required for nitrification was obtained by injecting $200 \mathrm{mg} / \mathrm{L}$ of $\mathrm{NaHCO}_{3}$ during the operation period.

\subsection{Reactor and Experimental Setup}

As shown in Fig. 1, a laboratory-scale SBR with an effective volume of $5 \mathrm{~L}$ (length: $15 \mathrm{~cm}$; width: $15 \mathrm{~cm}$; height: $22.2 \mathrm{~cm}$ ) was used in the experiments. A peristaltic pump was used to feed the influent into the reactor. The effluent was drawn at a height of $11.1 \mathrm{~cm}$ from the bottom of the reactor by a solenoid valve, and the volume exchange rate for every cycle was $50 \%$. Air was introduced by an air diffuser at the bottom of the reactor with an aeration flow rate of $2 \mathrm{~L} / \mathrm{min}$ to maintain dissolved oxygen (DO) concentration of $1.0-2.0 \mathrm{mg} / \mathrm{L}$ during the aerobic period. The SBR operation consisted of three cycles per day. Each cycle lasted $8 \mathrm{~h}$, including feeding (10 min), aeration (270 min), anoxic phase (150 min), settling (10 min), decanting (10 min), and an idle period (30 min) (Table 2). The SBR cycle times were controlled using a programmable logic controller (PLC). For the evaluation of the nitrogen removal efficiency and the AGS formation characteristics under varying salinity conditions, the injection of salts was increased from 0.5 to 1.0, 1.5, 2.0, 2.5, and 3.0 wt.\% in the experiment. The initial mixed liquor suspended solid (MLSS) and mixed liquor volatile suspended solid (MLVSS) in the reactor were 3,070 and 2,730 mg/L, respectively. To evaluate the nitrogen removal efficiency, a specific nitrification rate (SNR) and specific denitrification rate (SDNR) was derived in the final phase of the experiment under each condition.

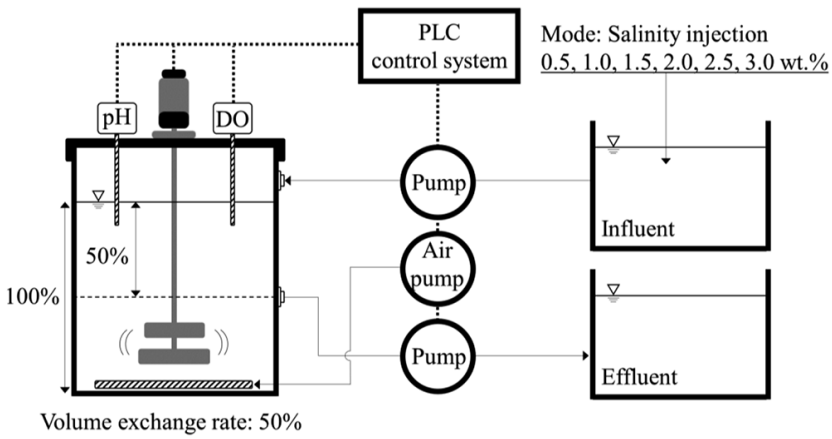

Fig. 1. Schematic diagram of lab. scale reactor.

Table 1. Characteristics of Salinity Wastewater (unit: $\mathrm{mg} / \mathrm{L}$ )

\begin{tabular}{|c|c|c|c|c|c|c|}
\hline Mode (Salinity) & $\mathrm{Cl}^{-}$ & $\mathrm{Na}^{+}$ & $\mathrm{SO}_{4}{ }^{2-}$ & $\mathrm{Mg}^{2+}$ & $\mathrm{Ca}^{2+}$ & $\mathbf{K}^{+}$ \\
\hline 1 (0.5 wt.\%) & $2,783.3$ & $1,516.7$ & 395.0 & 200.0 & 66.7 & 66.7 \\
\hline 2 (1.0 wt.\%) & $5,566.7$ & $3,033.3$ & 790.0 & 400.0 & 133.3 & 133.3 \\
\hline 3 (1.5 wt.\%) & $8,350.0$ & $4,550.0$ & $1,185.0$ & 600.0 & 200.0 & 200.0 \\
\hline 4 (2.0 wt.\%) & $11,133.3$ & $6,066.7$ & $1,580.0$ & 800.0 & 266.7 & 266.7 \\
\hline 5 (2.5 wt.\%) & $13,916.7$ & $7,583.3$ & $1,975.0$ & $1,000.0$ & 333.3 & 333.3 \\
\hline 6 (3.0 wt.\%) & $16,700.0$ & $9,100.0$ & $2,370.0$ & $1,200.0$ & 400.0 & 400.0 \\
\hline
\end{tabular}

Table 2. Experimental Conditions of Lab. Scale Reactor

\begin{tabular}{lcccccc}
\hline Vol. (L) & Flow (L/day) & Cycles/day & pH & HRT (h) & SRT (d) & Temp. ( $\left.{ }^{\circ} \mathbf{C}\right)$ \\
\hline 5 & 7.5 & 3 & $7.0-7.5$ & 16 & $20-25$ & $25 \pm 2$ \\
\hline & 1 cycle time $(\mathrm{min}):$ feeding(10) $\rightarrow$ aeration(270) $\rightarrow$ anoxic(150) $\rightarrow$ settlling(10) $\rightarrow \operatorname{decanting}(10) \rightarrow$ idle(30)
\end{tabular}




\subsection{Analytical Methods}

The reactor effluent was sampled seven times a week. The water was centrifuged at 4,000 rpm for $10 \mathrm{~min}$ to test the COD according to the standard method (5220-B) [37]. The samples for the detection of $\mathrm{NH}_{4}{ }^{+}-\mathrm{N}, \mathrm{NO}_{2}{ }^{-} \mathrm{N}$, and $\mathrm{NO}_{3}{ }^{-}-\mathrm{N}$ were filtered by $0.45 \mu \mathrm{m}$ glass fiber filter and tested by the standard methods $\left(4500-\mathrm{NH}_{3}-\mathrm{C}\right.$, 4500- $\mathrm{NO}_{2}-\mathrm{B}$, and $4500-\mathrm{NO}_{3}-\mathrm{B}$, respectively) [37]. The sludge physical properties included the MLSS, MLVSS, and sludge volume index $\left(\mathrm{SVI}_{30}\right)$. MLSS, MLVSS, and $\mathrm{SVI}_{30}$ were measured according to the standard methods (2540-B, D, 2540-E, and 2710-D, respectively) [37]. The EPS of the granules were extracted using formaldehyde and $\mathrm{NaOH}$ [38]. The contents of the extracted proteins (PN) and polysaccharides (PS) were measured using Folin's reagent [39] and phenol-vitriol colorimetry [40], respectively. The change in surface shape and the characteristics of AGS were examined using an optical microscope (CX31; Olympus Corp., Japan) and the collected sludge was covered with cover glass of $0.17 \mathrm{~mm}$ thickness and observed at 40x magnification.

\subsection{Microbial Community}

Pyrosequencing data analysis was performed to observe the microbial community. The community analysis was performed to determine the AGS characteristics of the initial phase and the difference in the end phase. Each sludge sample was homogenized (MP-80; Hanil, Korea). The homogenized sample was centrifuged to discard the supernatant, and DNA extraction was carried out in accordance with the manual provided by the manufacturer. The FastDNA Spin Kit for Soil (MP Biomedicals, Santa Ana, CA, USA) was used for DNA extraction. Polymerase chain reaction (PCR) (C1000 Touch Thermal Cycler, Bio-Rad, and Hercules, CA, USA) was performed using $1 \mu \mathrm{L}$ of extracted DNA. The initial denaturation was performed at $95^{\circ} \mathrm{C}$ for $5 \mathrm{~min}$. Subsequently, all procedures (denaturation at $95^{\circ} \mathrm{C}$ for $30 \mathrm{~s}$, annealing at $55^{\circ} \mathrm{C}$ for $30 \mathrm{~s}$, extension at $72^{\circ} \mathrm{C}$ for $30 \mathrm{~s}$, and final extension at $72^{\circ} \mathrm{C}$ for $7 \mathrm{~min}$ ) were 30 cycles each and fixed at $4^{\circ} \mathrm{C}$. For PCR, the purity of the DNA was increased using the QIAquick PCR Purification Kit (Qiagen, Valencia, CA, USA). Pyrosequencing of the amplified

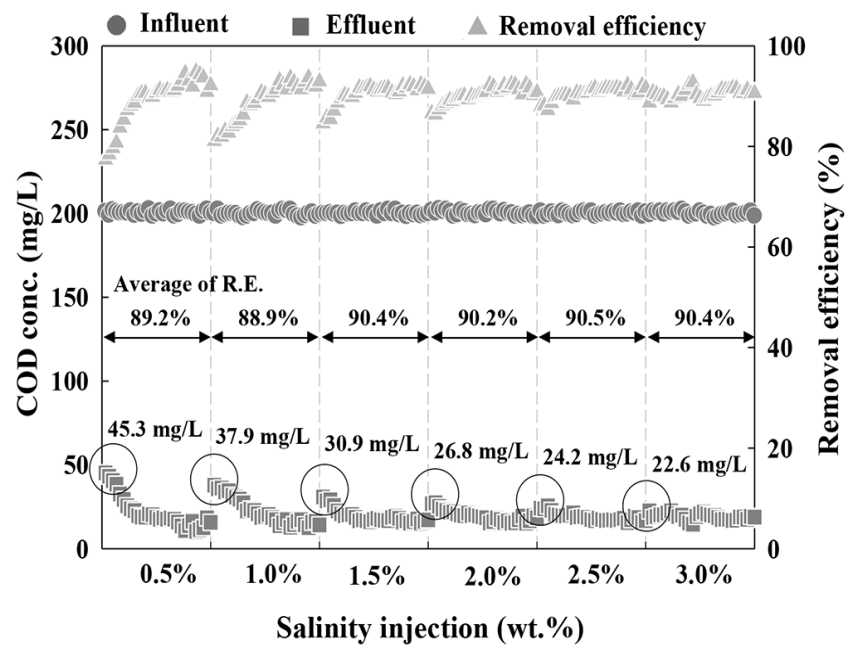

Fig. 2. Results of COD concentration with salinity injection.

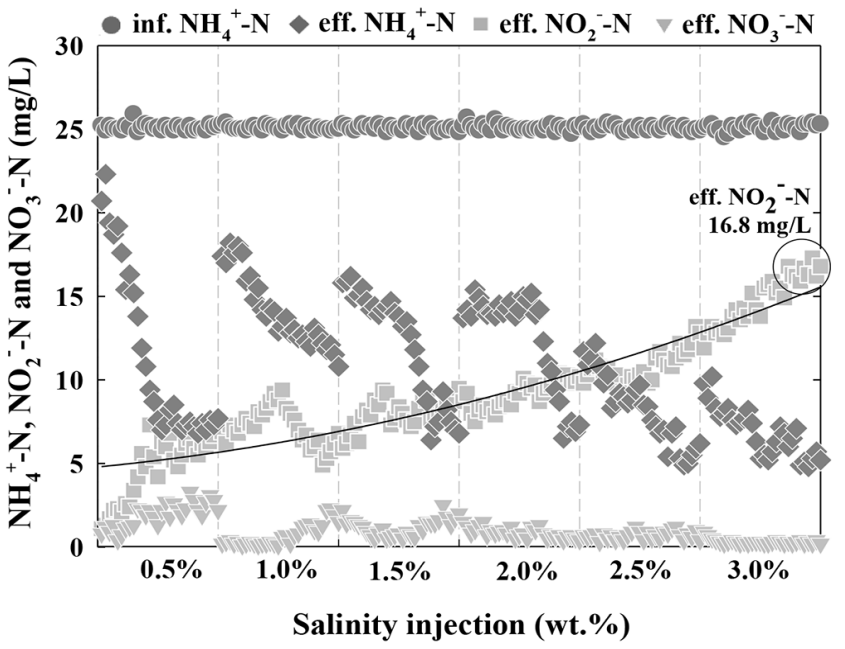

Fig. 3. Results of nitrogen compounds concentration with salinity injection.

DNA samples was conducted using a 454 GS FLX Junior Sequencing System (Roche, Branford, CT, USA). The resulting data was analyzed through the CLcommunity program (Chunlab Inc., Seoul, Korea) [41].

\section{Results and Discussion}

\subsection{Reactor Performance}

The reactor performance in terms of COD removal efficiency during the experiment is presented in Fig. 2. Based on the analysis results, the average COD removal efficiency was approximately $90 \%$ (88.9 $90.5 \%)$ for the duration of the operation. Also, the concentration of the treated water was gradually reduced at the start of each condition. In addition, a gradual recovery of the removal efficiency was observed after 1-2 weeks of operation. These results may be explained by the fact that the AGS adapted to the gradual increase in salinity. The effluent COD result is always taken as an index of the metabolic activity of heterotrophic bacteria [42, 43]. In Fig. 2 , the effluent COD concentration changed significantly when the influent salinity was increased from 0.5 up to 3.0 wt.\%. These results indicate that the microorganisms removing the COD were not sensitive to salt stress, which agrees with previous reports [44, 45]. Taheri et al. [33] performed long-term (269 d) observation of the COD removal efficiency in AGS using the SBR process by increasing the salt concentration $(\mathrm{NaCl})$ from 0.2 to $1.0 \%$, and achieved a removal efficiency of more than $90 \%$ for the duration of the operation. The stable COD removal efficiency against the increasing salt content was attributed to the microbial organic matter removal mechanism adaptability to the salinity, which was similar to the conclusion drawn in this study. Vo et al. [46] investigated the growth dynamics of freshwater and marine microalgae with supported biochemical performance in saline wastewater and the assimilation of pollutants by a developed method. They reported that the highest total organic carbon (TOC) removal efficiency occurred at salinities of 0.1 and 1\%. Typically for Chlorella vulgaris, 
92\% of the TOC was removed in $10 \mathrm{~d}$ and this corresponded to $0.1 \%$ salinity. At $1 \%$ salinity and similar hydraulic retention time (HRT), approximately 50\% of the TOC was eliminated. It is considered that the achieved COD removal efficiency in this study is comparable to that in other studies. Table S1 compares the COD removal efficiency by salinity injection [33, 34, 47-53].

The courses of nitrogen compounds are indicated in Fig. 3. The mean removal efficiency of $\mathrm{NH}_{4}{ }^{+}-\mathrm{N}$ ranged from 43.7 to $72.6 \%$ for the duration of the operation. Similar to the foregoing COD result, the $\mathrm{NH}_{4}{ }^{+}-\mathrm{N}$ removal efficiency gradually recovered in line with the microbial acclimation, and notably, with the increase in the injected $\mathrm{NaCl}, \mathrm{NO}_{2}{ }^{-}-\mathrm{N}$ gradually accumulated up to 16.8 $\mathrm{mg} / \mathrm{L}$ by the end of the operation [54]. Comparable to the study by Wan et al. [53], in which the $\mathrm{NaCl}$ was increased up to $5 \%$ in a partial nitrification of $\mathrm{NH}_{4}{ }^{+}-\mathrm{N}$, this finding seems attributable to the nitrite oxidizing bacteria (NOB), which are more susceptible to the inhibitory effects of salinity than the ammonia oxidizing bacteria (AOB). The increase in salinity could induce stress in microbial species, resulting in the decrease of cellular activities and even plasmolysis $[44,55]$. These changes slow down the microbial substrate utilization rate and cause the release of intracellular constituents as the salinity increases [56]. In addition, nitrite reductase is more sensitive than nitrate reductase to environment changes [57], thus leading to $\mathrm{NO}_{2}^{-}-\mathrm{N}$ accumulation. Table $\mathrm{S} 2$ compares the $\mathrm{NH}_{4}{ }^{+}-\mathrm{N}$ removal efficiency by salinity injection [19, 34, 48, 58-63].

Fig. 4 shows the SNR and SDNR values by salinity under each condition. Based on the analysis results, with the increase in the injected $\mathrm{NaCl}$, the mean SNR decreased from 0.112 to $0.040 \mathrm{mg}$ $\mathrm{NH}_{4}{ }^{+}-\mathrm{N} / \mathrm{mg}$ MLVSS $\mathrm{d}$, while the mean SDNR fell from 0.094 to $0.037 \mathrm{mg} \mathrm{NO}{ }_{3}^{-}-\mathrm{N} / \mathrm{mg}$ MLVSS $\mathrm{d}$. The decreasing trend of SNR was different from the results obtained by Zhao et al. [48]. They reported that the removal efficiency of $\mathrm{NH}_{4}{ }^{+}-\mathrm{N}$ was not significantly affected when the salinity was lower than $20 \mathrm{~g} / \mathrm{L}$. This difference may result from the diversity of treatment process and the microbial species. Also, when abruptly exposed to the higher salinity environment, bacterial cells might remain in a state of plasmolysis, resulting in the decline of denitrifying activities [64]. Kinyage et al. [65] used the recirculating aquaculture system (RAS) biofilters to analyze the $\mathrm{NH}_{4}{ }^{+}-\mathrm{N}$ removal rate by radically changing the salinity. They reported that very little of the $\mathrm{NH}_{4}{ }^{+}-\mathrm{N}$ was removed and none of the $\mathrm{NO}_{2}^{-}-\mathrm{N}$ was removed when the salinity was increased from 0 to $3.5 \%$. Ji et al. [62] used the $\mathrm{NO}_{2}{ }^{-}-\mathrm{N}$ accumulating granular sludge to analyze the partial denitrification performance and microbial community formation resulting from the phased increase in salinity. They reported that when the salt injection was increased from $0 \%$ up to $1.5 \%$ in phases, the denitrification rates showed a linear decrease, which parallels the present finding. In addition, they argued that all microbial species were subject to salinity limits, beyond which their activity declined, and emphasized the need for microbial acclimation to salinity via a phased increase in salinity.

Considering that the abovementioned studies differ from the present study in terms of reactor types, salt injection conditions ( $\mathrm{NaCl}$ only), operating conditions, and sludge types, it is rather implausible to compare the findings. Nonetheless, the reported decline in microbial activity and treatment efficiency with the increase in salinity bears a close parallel to the present finding,

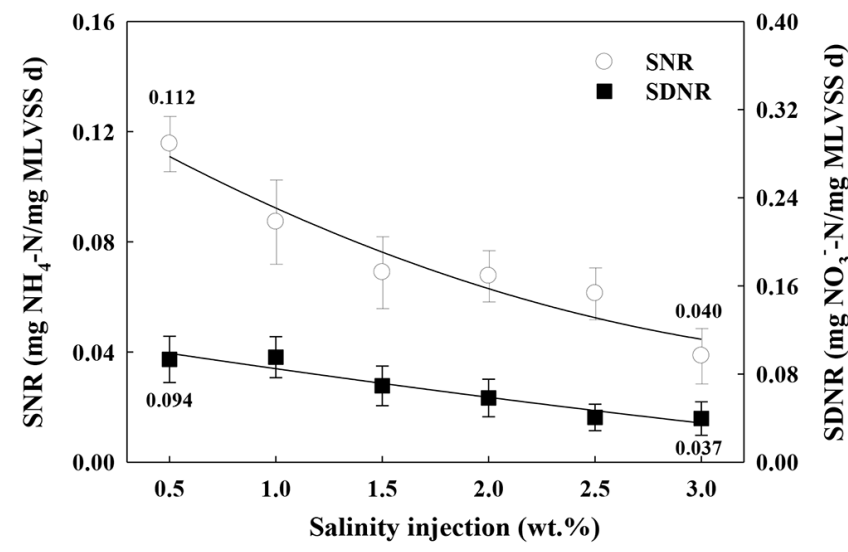

Fig. 4. Results of SNR and SDNR value with salinity injection.

and the derived results for SNR and SDNR appear to serve as applicable reference data and design factors conducive to designing bioreactors for AGS-based treatment of high-salinity wastewater.

\subsection{Extracellular Polymeric Substance}

The EPS, which includes both bound and soluble polymers [66, 67], could improve the hydrophobicity and polymeric interactions, as well as create bridges between the cells and cages to entrap cells [68]. EPS also had merits in the maintenance of the microorganisms under various environments, protecting them from harm [69]. PS usually acts as the main cross-network structure as well as an adhesive to trap and collect bacteria in the AGS [70, 71]. In addition, PN can reduce the electrostatic repulsion between bacteria and increase the aggregation of AGS by enhancing the surface hydrophobicity [72].

Fig. 5 shows the PN and PS content, and the PS/PN ratio of AGS under each salinity condition. With varying levels of salinity concentration, the total EPS increased from 107 to $132 \mathrm{mg} / \mathrm{g}$ MLVSS. These results could be explained by the protective response of the AGS to salt toxicity. EPS are metabolic products that accumulate on the surface of bacterial cells, and are considered important constituents of sludge floc, providing a protective barrier against the effects of toxic chemicals [69]. Thus, the response of the bacteria in AGS to higher increments of salinity concentration is to secrete more EPS. The PN and PS compositions varied with the salinity concentration. With the injected salinity levels ranging from 0.5 to 3.0 wt.\%, PN increased marginally from 78 to $84 \mathrm{mg} / \mathrm{g}$ MLVSS, whereas PS increased substantially from 29 to $48 \mathrm{mg} / \mathrm{g}$ MLVSS. Consequently, the PS/PN ratio rose from 0.37 to 0.57 . Reported as a primary factor for the AGS formation, the EPS result parallels the results obtained by Mesdaghinia et al. [73] and Fang et al. [74], who attributed the change in EPS composition to the rising salinity conditions stimulating the PS release from the AGS. Guo et al. [75] investigated the effect of salinity on MBR performance and also found that the salinity shock caused a higher influence ion PS than on PN with a salinity concentration of $0.75 \%$ and $1.5 \% \mathrm{NaCl}$; the changes to PS in EPS were considered to be closely correlated with certain saline-resistance genera. Also, Kim et al. [76] investigated the effects of the calcium ions in reverse osmosis (RO) 


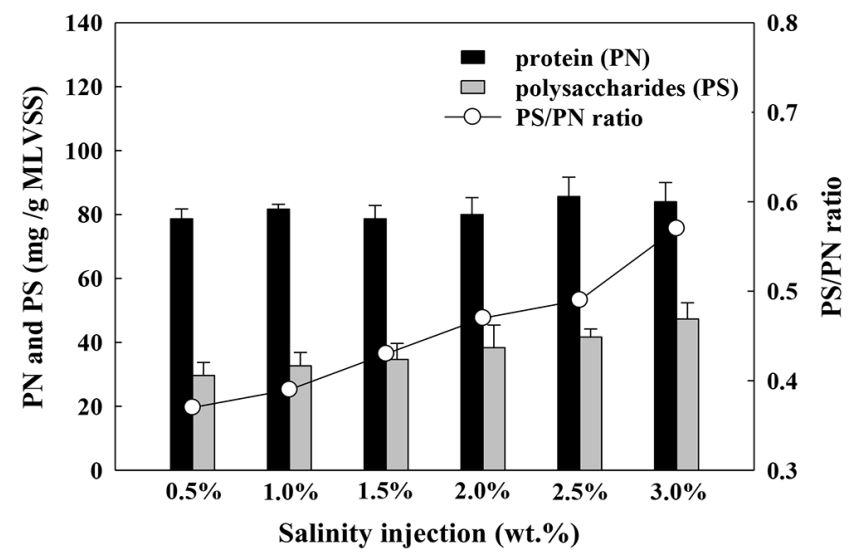

Fig. 5. Results of PN, PS and PS/PN ratio value with salinity injection.

concentrates on biological nitrogen removal and adsorption. They reported that depending on the injected concentration of calcium ions, the adsorption of calcium ions onto the negatively charged microbial surface boosted the production of PS, which increased the intercellular adhesion, played an important role in microbial flocculation, facilitated the AGS formation, and contributed to the growth of granules. Table S3 compares the EPS secreted efficiency by salinity injection [34, 77-82].

\subsection{MLSS and $\mathrm{SV}_{130}$}

Fig. S1 shows the behavior of MLSS and MLVSS by condition. Fig. S2 illustrates $\mathrm{SVI}_{30}$. Initially, the MLSS and MLVSS concentrations were 3,070 and $2,730 \mathrm{mg} / \mathrm{L}$, respectively. In tandem with the increase in the injected salinity concentration up to 3.0 wt.\%, the MLSS and MLVSS concentrations gradually increased up to 4,560 and 3,170 mg/L, respectively, by the end of the operation. That is, MLVSS did not change substantially compared with MLSS. Thus, the percentage of MLVSS in the entire MLSS (MLVSS/MLSS ratio) was 0.81 initially, which decreased to 0.69 by the end of the operation (3.0 wt.\% salinity). Salinity varying from 0.5 to 3.0 wt.\% exerted a positive influence on the biomass growth rate. A greater volume of inorganic materials accumulated in the granules under higher salinity conditions, resulting in a higher MLSS concentration in the reactor [83, 84].

Park and Lee [85] investigated the denitrification reaction of acid pickling wastewater containing a high concentration of $\mathrm{NO}_{3}^{-}-\mathrm{N}$ by injecting calcium ions, and reported that the MLVSS/MLSS ratio, which was 0.74 before the calcium ion injection, decreased to 0.69 following the injection of $1,000 \mathrm{mg} / \mathrm{L}$ calcium ions. They explicated that the specific gravity of the sludge increased due to the incremental injection of calcium ions adsorbed onto the microbial surface. They also reported that the adsorbed calcium ions underwent denitrification and bonded with $\mathrm{OH}$ ions to form $\mathrm{CaOH}_{2}$ sedimentation, which contributed to the increase in the specific gravity of the sludge. Similarly, in this study, the higher the injected $\mathrm{NaCl}$, the lower the MLVSS/MLSS ratio, and the increase in the specific gravity of the sludge seems attributable to the bonding with the cations contained in the salt. In biological wastewater treatment systems, part of the produced sludge (excess sludge) must be extracted and disposed of in a safe, cost-effective manner.
In addition, the handling of excess sludge is a primary concern in biological wastewater treatment. Consequently, further study on the treatment and management of excess sludge is needed in the biological treatment of high-salinity wastewater.

As for $\mathrm{SVI}_{30}$, contrary to the expectation that the increase in the $\mathrm{NaCl}$ would lead to an increase in osmotic pressure and microbial deflocculation, which would result in sludge with poor settling characteristics, the analysis results indicated the gradual improvement in sedimentation. With the increasing $\mathrm{NaCl}$ levels, the $\mathrm{SVI}_{30}$ decreased linearly from 88 to $58 \mathrm{~mL} / \mathrm{g}$, indicative of a very good sedimentation of sludge. These results could be explained as follows: inorganic materials accumulated inside the AGS, which increased the density of the AGS. As the density is defined as the mass per volume AGS, the density is increased by the salinity, which in turn affects the settling velocity [32]. This finding may also be explained by the aforementioned increase in the MLSS, and by the selection pressure operating strategy, where a short sedimentation time (10 $\mathrm{min}$ ) was maintained to accelerate the microbial aggregation and to continuously discharge sludge with poor settling characteristics [86-88].

\subsection{Microscopic Observation of AGS}

Fig. S3 shows the microorganisms observed with an optical microscope under varying conditions. As the abovementioned analysis results for MLSS and $\mathrm{SVI}_{30}$, microbial deflocculation was not observed for the duration of the operation, while clear forms of sludge were intuitively observed as the salinity increased. Also, the AGS, which initially measured $0.2 \mathrm{~mm}$, grew to approximately $0.8-1.0 \mathrm{~mm}$ as the MLSS increased. This finding is consistent with $\mathrm{Li}$ et al. [84], who reported that the salt contained in seawater facilitated the EPS of microorganisms, increased the density and aggregation, and thus accelerated the general microbial AGS formation. In addition, observing the formation of marine microbial granular sludge under varying conditions of solid retention time (SRT) and salinity, Corsino et al. [81] reported that the injection of $40 \mathrm{~g}$ of $\mathrm{NaCl} / \mathrm{L}$ yielded approximately $4 \mathrm{~mm}$ of granular sludge on average. $\mathrm{Ou}$ et al. [78] increased the salinity in phases from $0 \%$ to $9.0 \%$, observed the density of wastewater rising in line with the salinity with only large-sized sludge remaining in the reactor, and considered the high salinity a principal variable inducing the formation of AGS. Thus, it is considered that modification in cell morphology such as aggregation and elongation and the cytoplasm volume, under various salinity conditions is a familiar response of certain bacteria [33].

To sum up the foregoing findings, high salinity leads to the formation of AGS, which suggests that a dominance of microorganisms adapted to salt will maintain a stable granular sludge under varying salinity levels in the long-term operation of a biological treatment system.

\subsection{Microbial Communities of AGS}

Fig. S4 shows the richness of microbial species for the AGS prior to and at the end of the experiment based on the pyrosequencing results, and the relationships between the total valid reads and the operational taxonomic units (OTUs). The OTUs of the samples in the initial and final phases were 1,112 and 853, respectively, 
indicating that the microbial species are less diverse in the final phase. This finding may be ascribable to the dominance of microbial species adapted to the gradually increasing salinity injected into the AGS. Fig. 6 shows the pyrosequencing result of the analysis of microbial communities in the initial-phase (prior to experiment) and the end-phase AGS using the dynamic pie chart (krona). The groups of initial-phase AGS and end-phase AGS differ from each other. Proteobacteria in the initial- and end-phase AGS under phylum conditions accounted for the highest percentages (65.6 and 59.2\%, respectively) [41]. Also, Bacteroidetes accounted for 17.2 and $26.5 \%$, respectively, indicating a slight increase in the final phase. The dominance rates of Bacteroidetes and Firmicutes are reported to rise under high-salinity conditions, which parallel the present findings [24, 81, 89, 90].

Under the genus condition, Nitrosomonas accounted for $22.9 \%$ in the initial phase while the halophilic (salt-tolerating) Halomonas was dominant in the final phase, accounting for $43.2 \%$ (Fig. S5).

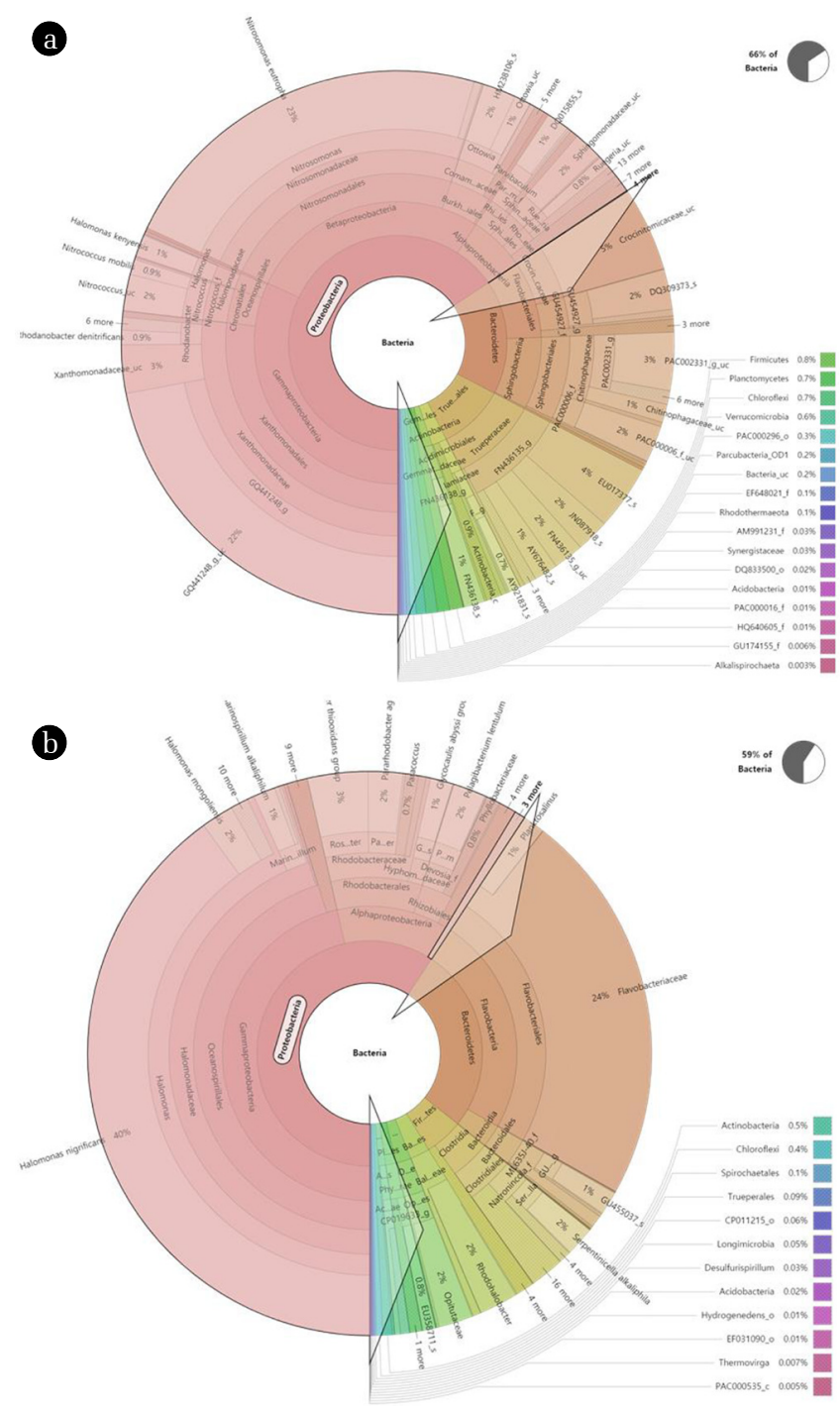

Fig. 6. Results of microbial communities using dynamic pie chart (Krona). (a) Initial phase AGS and (b) End phase AGS.
Nitrosomonas relevant to nitrification was hardly observed in the final phase with Halomonas being dominant, which seems to explain the present finding that the nitrification efficiency declined with the increase in the injected $\mathrm{NaCl}$. From the perspective of microbial functional groups, the existence of halophilic or halotolerant bacteria facilitated the adaption of AGS to a saline environment. Moreover, the saline conditions stimulated the bacteria to produce more EPS to protect themselves from an adverse environment. With the increase in salinity step by step, an AGS system dominated by moderately halophilic genera was gradually formed with an increasing relative abundance of Halomonas. Moreover, Halomonas is a member of the family Halomonadaceae, which shows remarkable versatility with respect to salt tolerance [91]. Also, Wang et al. [34] reported that Halomonas was found under $7-8 \%$ salinity conditions, and that optimal growth was viable when the maximum salinity was $10 \%$ and $\mathrm{NO}_{3}{ }^{-} \mathrm{N}$ was used as the electron acceptor [92], which is similar to the results in the present study excluding a slight difference in the rates of microbial communities.

\section{Conclusions}

This study investigated the characteristic biological removal of nitrogen and the formation of AGS under the gradually increased seawater salinity conditions in a SBR. Overall, the removal efficiency of $\mathrm{COD}$ and $\mathrm{NH}_{4}{ }^{+}-\mathrm{N}$ by salinity injection showed a tendency to gradually stabilize as the AGS adapted to the salinity. The stable COD removal efficiency against the increasing salt content was attributed to the microbial organic matter removal mechanism adaptability to the salinity. Similar to the foregoing COD result, the $\mathrm{NH}_{4}{ }^{+}-\mathrm{N}$ removal efficiency gradually recovered in line with the microbial acclimation, and notably, with the increase in the injected $\mathrm{NaCl}$. Moreover, the increased salinity conditions stimulated the release of PS from the AGS, which contributed to the formation of AGS. In the microbial community analysis, under the genus condition, Nitrosomonas accounted for $22.9 \%$ in the initial phase, whereas the halophilic Halomonas was dominant, accounting for $43.2 \%$ in the final phase. Hence, the gradually increased salinity appears to facilitate the dominance of halophilic microorganisms (Halomonas) in the long-term operation of an AGS-based biological treatment system and the stable retention of AGS, which warrants further study using real seawater.

\section{Acknowledgements}

This subject is supported by Korea Ministry of Environment as "Global Top Project" (Project No.:2016002190006).

\section{Author Contributions}

H.G.K. (Ph.D.) conducted all the experiments. D.H.A (Professor) wrote the manuscript. 


\section{References}

1. Tam VT, Batelaan O, Le TT, Nhan PQ. Three-dimensional hydrostratigraphical modelling to support evaluation of recharge and saltwater intrusion in a coastal groundwater system in Vietnam. Hydrogeol. J. 2014;22:1749-1762.

2. Zhu L, Gong H, Li X, et al. Land subsidence due to groundwater withdrawal in the northern Beijing plain, China. Eng. Geol. 2015;193:243-255.

3. Wen X, Lu J, Wu J, Lin Y, Luo Y. Influence of coastal groundwater salinization on the distribution and risks of heavy metals. Sci. Total Environ. 2019;652:267-277.

4. Ismail SB, Jeison GD, van Lier JB. Effects of high salinity wastewater on methanogenic sludge bed systems. Water Sci. Technol. 2008;58:1963-1970.

5. Guo N, Wang Y, Tong T, Wang S. The fate of antibiotic resistance genes and their potential hosts during bio-electrochemical treatment of high-salinity pharmaceutical wastewater. Water Res. 2018;133:79-86.

6. Huang X, Yang J, Wang J, Bi J, Xie C, Hao H. Design and synthesis of core-shell $\mathrm{Fe}_{3} \mathrm{O}_{4} @$ PTMT composite magnetic microspheres for adsorption of heavy metals from high salinity wastewater. Chemosphere 2018;206:513-521.

7. Wen J, Dong H, Zeng G. Application of zeolite in removing salinity/sodicity from wastewater: A review of mechanisms, challenges and opportunities. J. Clean. Prod. 2018;197:1435-1446.

8. Peng X, Zheng D, Xu H. The feasibility and mechanism of reverse electrodialysis enhanced photocatalytic fuel cell-Fenton system on advanced treatment of coal gasification wastewater. Sep. Purif. Technol. 2019;220:183-188.

9. Rae IB, Pap S, Svobodova D, Gibb SW. Comparison of sustainable biosorbents and ion-exchange resins to remove $\mathrm{Sr}^{2+}$ from simulant nuclear wastewater: Batch, dynamic and mechanism studies. Sci. Total Environ. 2019;650:2411-2422.

10. Tan X, Acquah I, Liu H, Li W, Tan S. A critical review on saline wastewater treatment by membrane bioreactor (MBR) from a microbial perspective. Chemosphere 2019;220:1150-1162.

11. Liang Y, Zhu H, Bañuelos G, et al. Constructed wetlands for saline wastewater treatment: A review. Ecol. Eng. 2017;98: 275-285.

12. Ahn YH, Lee JW, Kim HC, Kwon SY. Lithoautotrophic nitrogen removal with anaerobic granular sludge as seed biomass and its microbial community. Environ. Eng. Res. 2006;11:173-180.

13. O’Neill FJ, Bromley-Challenor KCA, Greenwood RJ, Knapp JS. Bacterial growth on aniline: implications for the biotreatment of industrial wastewater. Water Res. 2000;34:4397-4409.

14. Oie CSI, Albaugh CE, Peyton BM. Benzoate and salicylate degradation by Halomonas campisalis, an alkaliphilic and moderately halophilic microorganism. Water Res. 2007;41:1235-1242.

15. Rivadeneyra MA, Martin-Algarra A, Sanchez-Navas A, Martin-Ramos D, Carbonate and phosphate precipitation by Chromohalobacter marismortui. Geomicrobiol. J. 2006;23: 89-101.

16. van den Bogaart G, Hermans N, Krasnikov V, Poolman B. Protein mobility and diffusive barriers in Escherichia coli: consequences of osmotic stress. Mol. Microbiol. 2007;64:858-871.

17. Khengaoui K, Mahammed MH, Touil Y, Amrane A. Influence of Secondary Salinity Wastewater on the Efficiency of Biological Treatment of Sand Filter. Energy Procedia 2015;74:398-403.

18. Liu M, Li Q, Sun H, et al. Impact of salinity on antibiotic resistance genes in wastewater treatment bioreactors. Chem. Eng. J. 2018;338:557-563.

19. Chen X, Wang X, Chen X, et al. Salt inhibition on partial nitritation performance of ammonium-rich saline wastewater in the zeolite biological aerated filter. Bioresour. Technol. 2019;280:287-294.

20. Zhang Y, Kuroda M, Arai S, Kato F, Inoue D, Lke M. Biological treatment of selenate-containing saline wastewater by activated sludge under oxygen-limiting conditions. Water Res. 2019;154:327-335.

21. Moon BH, Park KH, Kim SS, Yoon CH. Effects of aerobic and non-aerobic starvation on SBR performance when treating saline wastewater. Environ. Eng. Res. 2012;17:139-144.

22. Zhang Y, Li B, Xu R-X, Wang G-X, Zhou Y, Xie B. Effects of pressurized aeration on organic degradation efficiency and bacterial community structure of activated sludge treating saline wastewater. Bioresour. Technol. 2016;222:182-189.

23. Tan S, Cui C, Hou Y, et al. Cultivation of activated sludge using sea mud as seed to treat industrial phenolic wastewater with high salinity. Mar. Pollut. Bull. 2017;114:867-870.

24. He H, Chen Y, Li X, Cheng Y, Yang C, Zeng G. Influence of salinity on microorganisms in activated sludge processes: A review. Int. Biodeterior. Biodegrad. 2017;119:520-527.

25. Hu Y-Q, Wei W, Gao M, Zhou Y, Wang G-X, Zhang Y. Effect of pure oxygen aeration on extracellular polymeric substances (EPS) of activated sludge treating saline wastewater. Process Saf. Environ. Prot. 2019;123:344-350.

26. Chen C, Ming J, Yoza BA, et al. Characterization of aerobic granular sludge used for the treatment of petroleum wastewater. Bioresour. Technol. 2019;271:353-359.

27. Wang X-C, Chen Z-L, Kang J, Zhao X, Shen J-M, Yang L. The key role of inoculated sludge in fast start-up of sequencing batch reactor for the domestication of aerobic granular sludge. J. Environ. Sci. 2019;78:127-136.

28. Yin Y, Sun J, Liu F, Wang L. Effect of nitrogen deficiency on the stability of aerobic granular sludge. Bioresour. Technol. 2019;275:307-313.

29. Lee HL, Ryu JH, Lee YP, et al. Aerobic granules for the effective oxidation of ammonium nitrogen. Environ. Eng. Res. 2014;19:23-29.

30. Jung Y-C, Adav SS, Lee D-J, Tay J-H. Stable aerobic granules for continuous-flow reactors: Precipitating calcium and iron salts in granular interiors. Bioresour. Technol. 2010;101:8051-8057.

31. Hao T, Wei L, Lu H, et al. Characterization of sulfate-reducing granular sludge in the SANI ${ }^{\circ}$ process. Water Res. 2013;47: 7042-7052.

32. Winkler MK-H, Bassin JP, Kleerebezem R, van der Lans RGJM, van Loosdrecht MCM. Temperature and salt effects on settling velocity in granular sludge technology. Water Res. 2012;46: 5445-5451.

33. Taheri E, Hajian MHK, Amin MM, Nikaeen M, Hassanzadeh A. Treatment of saline wastewater by a sequencing batch reactor with emphasis on aerobic granule formation. Bioresour. Technol. 2012;111:21-26. 
34. Wang Z, Gao M, She Z. Effects of salinity on performance, extracellular polymeric substances and microbial community of an aerobic granular sequencing batch reactor. Sep. Purif. Technol. 2015;144:223-231.

35. Shih Y-J, Hsia K-F, Chen C-W, Chen C-F, Dong C-D. Characteristics of trichloroethene (TCE) dechlorination in seawater over a granulated zero-valent iron. Chemosphere 2019;216:40-47.

36. Ahunbay MG. Achieving high water recovery at low pressure in reverse osmosis processes for seawater desalination. Desalination 2019;465:58-68.

37. APHA (American Public Health Association). Standard methods for the examination of water and wastewater. Washington D.C.:APHA; 2005.

38. Liu H, Fang HHP. Extraction of extracellular polymeric substances (EPS) of sludges. J. Biotechnol. 2002;95:249-256.

39. Lowry OH, Rosebrough NJ, Farr AL, Randall, RJ. Protein measurement with the Folin phenol reagent. J. Biol. Chem. 1951;193:265-275.

40. Herbert D, Philipps PJ, Strange RE. Carbohydrate analysis. Methods Enzymol. B. 1971;5:265-277.

41. Yae JB, Ryu JH, Tuyen NV, Kim HG, Hong SW, Ahn DH. An aerobic granular sludge process for treating low carbon/nitrogen ratio sewage. Environ. Eng. Res. 2019;24:238-245.

42. Moussa MS, Hooijmans CM, Lubberding HJ, Gijzen HJ, van Loosdrecht MC. Modelling nitrification, heterotrophic growth and predation in activated sludge. Water Res. 2005;39:5080-5098.

43. Zhai S, Ji M, Zhao Y, Pavlostathis SG, Zhao Q. Effects of salinity and $\mathrm{COD} / \mathrm{N}$ on denitrification and bacterial community in dicyclic-type electrode based biofilm reactor. Chemosphere 2018;192:328-336

44. Moussa MS, Sumanasekera DU, Ibrahim SH, et al. Long term effects of salt on activity, population structure and floc characteristics in enriched bacterial cultures of nitrifiers. Water Res. 2006;40:1377-1388.

45. Jang D, Hwang Y, Shin H, Lee W. Effects of salinity on the characteristics of biomass and membrane fouling in membrane bioreactors. Bioresour. Technol. 2013;141:50-56.

46. Vo HNP, Ngo HH, Guo W, et al. Identification of the pollutants removal and mechanism by microalgae in saline wastewater. Bioresour. Technol. 2019;275:44-52.

47. Wang Z, Gao M, Wang Z, et al. Effect of salinity on extracellular polymeric substances of activated sludge from an anoxic-aerobic sequencing batch reactor. Chemosphere 2013;93:2789-2795.

48. Zhao Y, Park HD, Park JH, et al. Effect of different salinity adaptation on the performance and microbial community in a sequencing batch reactor. Bioresour. Technol. 2016;216: 808-816.

49. Lefebvre O, Habouzit F, Bru V, Delgenes JP, Godon JJ, Moletta R. Treatment of hypersaline industrial wastewater by a microbial consortium in a sequencing batch reactor. Environ. Technol. 2004;25:543-553.

50. Dinçer AR, Kargi F. Performance of rotating biological disc system treating saline wastewater. Process Biochem. 2001;36:901-906.

51. Frank WB, Regnery J, Chan KE, Ramey DF, Spear JR, Cath TY. Co-treatment of residential and oil and gas production wastewater with a hybrid sequencing batch reactor-membrane bioreactor process. J. Water Process Eng. 2017;17:82-94.

52. Di Bella G, Di Trapani D, Freni G, Torregrossa M, Viviani G. Analysis of biomass characteristics in MBR and MB-MBR systems fed with synthetic wastewater: Influence of a gradual salinity increase. Chem. Eng. Trans. 2014;38:445-450.

53. Wan C, Yang X, Lee D-J, Liu X, Sun S, Chen C. Partial nitrification of wastewaters with high $\mathrm{NaCl}$ concentrations by aerobic granules in continuous-flow reactor. Bioresour. Technol. 2014; 152:1-6.

54. Ramaswami S, Uddin FMJ, Behrendt J, Otterpohl R. High-rate nitrification of saline wastewaters using fixed-bed reactors. $J$ Environ. Manag. 2019;243:444-452.

55. Rene ER, Kim SJ, Park HS. Effect of COD/N ratio and salinity on the performance of sequencing batch reactors. Bioresour. Technol. 2008;99:839-846.

56. Wang Z, Gao M, Wei J, et al. Long-term effects of salinity on extracellular polymeric substances, microbial activity and microbial community from biofilm and suspended sludge in an anoxic-aerobic sequencing batch biofilm reactor. J. Taiwan Inst. Chem. Eng. 2016;68:275-280.

57. Ghafari S, Hasan M, Aroua MK. Improvement of autohydrogenotrophic nitrite reduction rate through optimization of $\mathrm{pH}$ and sodium bicarbonate dose in batch experiments. J. Biosci. Bioeng. 2009;107:275-280.

58. She Z, Wu L, Wang Q, et al. Salinity effect on simultaneous nitrification and denitrification, microbial characteristics in a hybrid sequencing batch biofilm reactor. Bioprocess Biosyst. Eng. 2018;41:65-75.

59. Uygur A, Kargi F. Salt inhibition on biological nutrient removal from saline wastewater in a sequencing batch reactor. Enzyme Microb. Technol. 2004;34:313-318.

60. Giustinianovich EA, Campos JL, Roeckel MD, Estrada AJ, Mosquera-Corral A, Val del Río Á. Influence of biomass acclimation on the performance of a partial nitritation-anammox reactor treating industrial saline effluents. Chemosphere 2018;194:131-138.

61. Li J, Ye W, Wei D, et al. System performance and microbial community succession in a partial nitrification biofilm reactor in response to salinity stress. Bioresour. Technol. 2018;270: 512-518.

62. Ji J, Peng Y, Wang B, et al. Effects of salinity build-up on the performance and microbial community of partial-denitrification granular sludge with high nitrite accumulation. Chemosphere 2018;209:53-60

63. Ge CH, Dong Y, Li H, et al. Nitritation-anammox process a realizable and satisfactory way to remove nitrogen from high saline wastewater. Bioresour. Technol. 2019;275:86-93.

64. Kim LH, Chong TH. Physiological responses of salinity-Stressed Vibrio sp. and the effect on the biofilm formation on a nanofiltration membrane. Environ. Sci. Technol. 2017;51:1249-1258.

65. Kinyage JPH, Pedersen PB, Pedersen L-F. Effects of abrupt salinity increase on nitrification processes in a freshwater moving bed biofilter. Aquac. Eng. 2019;84:91-98.

66. Wu D, Li GF, Shi ZJ, et al. Co-inhibition of salinity and Ni(II) in the anammox-UASB reactor. Sci. Total Environ. 2019;669: 70-82.

67. Tang CJ, Zheng P, Wang $\mathrm{CH}$, et al. Performance of high-loaded ANAMMOX UASB reactors containing granular sludge. Water 
Res. 2011;45:135-144.

68. Ma C, Jin RC, Yang GF, Yu JJ, Xing BS, Zhang QQ. Impacts of transient salinity shock loads on anammox process performance. Bioresour. Technol. 2012;112:124-130.

69. Sheng GP, Yu HQ, Li XY. Extracellular polymeric substances (EPS) of microbial aggregates in biological wastewater treatment systems: A review. Biotechnol. Adv. 2010;28:882-894.

70. Vyrides I, Stuckey DC. Adaptation of anaerobic biomass to saline conditions: role of compatible solutes and extracellular polysaccharides. Enzym. Microb. Technol. 2009;44:46-51.

71. Alias MA, Muda K, Affam AC, Aris A, Hashim N. The effect of divalent and trivalent cations on aggregation and surface hydrophobicity of selected microorganism. Environ. Eng. Res. 2017;22:61-74.

72. Tsuneda S, Jung J, Hayashi H, Aikawa H, Hirata A, Sasaki $H$. Influence of extracellular polymers on electrokinetic properties of heterotrophic bacterial cells examined by soft particle electrophoresis theory. Colloids Surf. B Biointerf. 2003;29:181-188.

73. Mesdaghinia A, Ghahremani MH, Nabizadeh R, Nasseri S, Rafiee $\mathrm{M}$. Role of $\mathrm{COD}_{\mathrm{PCP}} / \mathrm{COD}_{\text {Total }}$ ratio on p-chlorophenol toxicity towards aerobic granular sludge. J. Ind. Eng. Chem. 2017;54:440-446.

74. Fang F, Yang M-M, Wang H, Yan P, Chen Y-P, Guo J-S. Effect of high salinity in wastewater on surface properties of anammox granular sludge. Chemosphere 2018;210:368-375.

75. Guo X, Miao Y, Wu B, et al. Correlation between microbial community structure and biofouling as determined by analysis of microbial community dynamics. Bioresour. Technol. 2015;197:99-105.

76. Kim HG, Kim SS, Kim SC, Joo HJ. Effects of $\mathrm{Ca}^{2+}$ on biological nitrogen removal in reverse osmosis concentrate and adsorption treatment. J. Ind. Eng. Chem. 2018;57:216-225.

77. Zhang L, Feng X, Zhu N, Chen J. Role of extracellular protein in the formation and stability of aerobic granules. Enzym. Microb. Technol. 2007;41:551-557.

78. Ou D, Li, W, Li, H, et al. Enhancement of the removal and settling performance for aerobic granular sludge under hypersaline stress. Chemosphere 2018;212:400-407.

79. Hou M, Li W, Li H, Li C, Wu X, Liu YD. Performance and bacterial characteristics of aerobic granular sludge in response to alternating salinity. Int. Biodeterior. Biodegradation 2019;142:211-217.

80. Wu X, Li W, Ou D, et al. Enhanced adsorption of $\mathrm{Zn}^{2+}$ by salinity-aided aerobic granular sludge: Performance and binding mechanism. J. Environ. Manag. 2019;242:266-271.

81. Corsino SF, Capodici M, Pippo FD, Tandoi V, Torregrossa M. Comparison between kinetics of autochthonous marine bacteria in activated sludge and granular sludge systems at different salinity and SRTs. Water Res. 2019;148:425-437.

82. Huang JL, Wang HH, Alam F, Cui YW. Granulation of halophilic sludge inoculated with estuarine sediments for saline wastewater treatment. Sci. Total Environ. 2019;682:532-540.

83. Corsino SF, Campo R, Bella GD, Torregrossa M, Viviani G. Cultivaotin of granular sludge with hypersaline oily wastewater. Int. Biodeterior. Biodegradation 2015;105:192-202.

84. Li X, Luo J, Guo G, Mackey HR, Hao T, Chen, G. Seawater-based wastewater accelerates development of aerobic granular sludge: A laboratory proof-of-concept. Water Res. 2017;115:210-219.

85. Park SJ, Lee SH. A study on the biological treatment of acid pickling wastewater containing a high concentration of nitrate nitrogen. J. Korean Soc. Water Environ. 2015;31:253-261.

86. Su KZ, Ni BJ, Yu HQ. Modeling and optimization of granulation process of activated sludge in sequencing batch reactors. Biotechnol. Bioeng. 2013;110:1312-1322.

87. Szabó E, Hermansson M, Modin O, Persson F, Wilén BM. Effects of wash-out dynamics on nitrifying bacteria in aerobic granular sludge during start-up at gradually decreased settling time. Water 2016;8:172.

88. de Sousa Rollemberg SL, Barros ARM, Firmino PIM, dos Santos AB. Aerobic granular sludge: Cultivation parameters and removal mechanisms. Bioresour. Technol. 2018;270:678-688.

89. Chen Y, He H, Liu H, et al. Effect of salinity on removal performance and activated sludge characteristics in sequencing batch reactors. Bioresour. Technol. 2018;249:890-899.

90. Zhang Y, Jiang W-L, Xu R-X, Wang G-X, Xie B. Effect of short-term salinity shock on unacclimated activated sludge with pressurized aeration in a sequencing batch reactor. Separ. Purif. Technol. 2017;178:200-206.

91. Vargas C, Nieto JJ. Genetic tools for the manipulation of moderately halophilic bacteria of the family halomonadaceae. Methods Mol. Biol. 2004;267:183-208.

92. Romano I, Lama L, Nicolaus B, Poli A, Gambacorta A, Giordano A. Halomonas alkaliphila sp. nov., a novel halotolerant alkaliphilic bacterium isolated from a salt pool in Campania (Italy). J. Gen. Appl. Microbiol. 2006;52:339-348. 